Jurnal Ilmu Komunikasi UHO : Jurnal Penelitian Kajian Ilmu Komunikasi dan Informasi.

Volume 6, No. 2, April 2021, hlm 179-193

\title{
IMPLEMENTASI KONSEP TRIPLE BOTTOM LINE PADA CSR PT. ANTAM, TBK SULAWESI TENGGARA KAB. KOLAKA
}

\author{
Sri Rahmisari Rembulan ${ }^{1}$, Laode Muh. Umran ${ }^{2}$, Muh. Rajab ${ }^{3}$ \\ Jurusan Ilmu Komunikasi, Fakultas Ilmu Sosial dan Ilmu Politik, Universitas Halu Oleo \\ Kampus Hijau Bumi Tridharma Anduonohu, Kendari, Indonesia
}

\begin{abstract}
ABSTRAK
Selama 44 tahun beroperasi bukanlah hal mudah bagi PT. ANTAM,Tbk Sulawesi Tenggara untuk terus dapat mempertahankan eksistensi, kredibilitasnya, dan citra positifnya di mata masyarakat hingga saat ini melalui program-program CSR yang dilaksanakan. Tujuan penelitian ini adalah menganalisis implementasi konsep Triple Bottom Line pada pelaksanaan CSR PT. ANTAM, Tbk Sulawesi Tenggara dengan menggunakan metode penelitian kualitatif. Informan dalam penelitian ini adalah CSR Manager PT. ANTAM, Tbk Kabupaten Kolaka Sulawesi Tenggara dan masyarakat Kecamatan Pomalaa dengan menetapkan informan sebanyak 11 (sebelas) orang yang ditentukan dengan menggunakan teknik purposive. Metode pengumpulan data yang digunakan adalah observasi, wawancara dan studi dokumen. Hasil penelitian menunjukkan bahwa (1) konsep Triple Bottom Line (profit, people, planet) diwujudkan dalam Master Plan CSR UBPN ANTAM Sultra melalui implementasi Program Community Development serta Program Kemitraan dan Bina lingkungan mencakup 6 bidang program yaitu pendidikan, kesehatan, ekonomi, sosial-budaya, lingkungan, dan penguatan kapasitas kelembagaan, (2) dalam tahapan pelaksanaan program terdapat keterlibatan masyarakat yang terlihat dari partisipasi serta antusiasme yang tinggi dalam tahap perencanaan program, pelaksanaan program dan monitoring pasca pelaksanaan program, serta pencapaian pelaksanaan program terlihat dari banyaknya manfaat dari setiap program CSR UBPN ANTAM Sultra yang telah dirasakan baik itu bagi kesejahteraan masyarakat maupun bagi lingkungan.
\end{abstract}

Kata-kata Kunci: Implementasi, Konsep Triple Bottom Line, CSR PT. ANTAM 


\title{
IMPLEMENTATION OF TRIPLE BOTTOM LINE CONCEPT IN THE CSR OF PT. ANTAM, TBK SOUTHEAST SULAWESI, KOLAKA REGENCY
}

\begin{abstract}
During 44 years of operation it was not easy for PT. ANTAM, Tbk Southeast Sulawesi to be able to maintain its existence, credibility, and a positive image in the community until now through its CSR programs implemented. The purpose of this research is to analyze the implementation of the Triple Bottom Line concept in the CSR implementation of PT. ANTAM, Tbk Southeast Sulawesi using qualitative research methods. The informants in this study were the CSR Manager of PT. ANTAM, Tbk, Kolaka Regency, Southeast Sulawesi and the people of Pomalaa District by assigning 11 (eleven) informants who were determined using a purposive technique. The data collection methods used were observation, interview and document study. The results of this research showed that (1) the concept of Triple Bottom Line (profit, people, planet) is embodied in the UBPN ANTAM Sultra CSR Master Plan through the implementation of the Community Development Program and the Partnership Program covering 6 program areas, there are education, health, economy, socialculture, environment, and strengthening of institutional capacity, (2) in the program implementation stage there is community involvement as seen from the high participation and enthusiasm in the program planning stage, program implementation and monitoring after program implementation, as well as program implementation achievements, seen from the many benefits of each ANTAM Sultra's CSR program which has been felt both for the welfare of the community and for the environment.
\end{abstract}

Keywords: Implementation; Triple Bottom Line Concept; CSR of PT. ANTAM 
Jurnal Ilmu Komunikasi UHO : Jurnal Penelitian Kajian Ilmu Komunikasi dan Informasi.

Volume 6, No. 2, April 2021, hlm 179-193

\section{PENDAHULUAN}

Dewasa ini, di berbagai belahan dunia, perusahaan mulai dituntut untuk mewujudkan rasa tanggungjawab sosialnya kepada publik dan tidak lagi hanya berfokus pada pendapatan profit saja. Hal ini telah menjadi tolak ukur bagi perusahaan untuk melaksanakan tanggung jawab sosialnya melalui konsep yang kita kenal dengan CSR atau Corporate Social Responsibility.

Sebagai salah satu perusahaan pertambangan terbesar di Asia Tenggara PT. ANTAM, Tbk (terbuka) yang memiliki komitmen penuh pada Corporate Social Responsibility (CSR) atau tanggung jawab sosial perusahaan sebagai aspek penting yang mendukung keberlanjutan hidup perusahaan. Bagi mereka CSR tidak hanya sekedar bentuk tanggung jawab sosial perusahaan, melainkan bagian dari resiko perusahaan yang harus dikelola dengan baik, karena sebagai perusahaan yang bergerak dibidang pertambangan PT. ANTAM, Tbk menyadari bahwa kegiatan operasional perusahaan secara langsung akan berdampak pada lingkungan dan masyarakat sekitar.

PT. ANTAM, Tbk sendiri merupakan perusahaan perseroan yang dimulai sejak tahun 1968 dan didirikan sebagai Badan Usaha Milik Negara melalui merjer dari beberapa Perusahaan tambang dan proyek tambang milik Pemerintah. PT. ANTAM, Tbk memiliki Visi yaitu "Menjadi korporasi global terkemuka melalui diversifikasi dan integrasi usaha berbasis Sumber Daya Alam" dengan salah satu misinya yaitu "Mengoptimalkan sumber daya dengan mengutamakan keberlanjutan, keselamatan kerja dan kelestarian lingkungan”.

Berdasarkan komitmen tanggung jawab sosial yang sejalan dengan misi perusahaan yaitu melaksanakan bisnis berkelanjutan, PT. ANTAM, Tbk memperhatikan tiga aspek penting Triple Bottom Line (profit, people, planet) yaitu pengelolaan aspek dampak lingkungan, sosial, dan ekonomi dari operasi perusahaan yang didalamnya termasuk pengelolaan aspek hubungan dengan masyarakat, kepatuhan terhadap regulasi dan dampak ekonomi terhadap masyarakat yang dituangkan melalui program-program CSR perusahaan itu sendiri.

Sebagai unit bisnis pertambangan nikel terbesar di Sulawesi Tenggara yang telah berdiri selama 44 tahun sejak pertama kali beroperasi pada tahun 1976 di Pomalaa Kabupaten Kolaka, tidak mudah bagi UBP Nikel Sulawesi Tenggara untuk terus dapat mempertahankan eksistensi, kredibilitasnya, dan citra positifnya di mata masyarakat hingga saat ini melalui program-program CSR yang dilaksanakan. Perlu bagi perusahaan untuk benar-benar mengintegrasikan kepentingan masyarakat kedalam kepentingan perusahaan. 
Jurnal Ilmu Komunikasi UHO : Jurnal Penelitian Kajian Ilmu Komunikasi dan Informasi.

Volume 6, No. 2, April 2021, hlm 179-193

Hal tersebutlah yang melatarbelakangi penelitian ini dimana peneliti ingin melihat bagaimana keterlibatan dan antusiasme langsung dari masyarakat dalam setiap tahapantahapan pelaksanaan CSR serta apa saja pencapaian dari program-program CSR UBP Nikel Sulawesi Tenggara yang telah dilaksanakan dilihat dari manfaat, dampak, dan keuntungan yang diberikan untuk terus dapat mempertahakankan eksistensi, kredibilitas, dan citra positifnya di masyarakat, yang mana hal tersebut dirasakan oleh peneliti sebagai suatu permasalahan yang harus ditemukan jawabannya.

Terdapat dua rumusan masalah dalam penelitian ini yakni bagaimana tahapan-tahapan pelaksanaan program CSR PT. ANTAM, Tbk Kabupaten Kolaka Sulawesi Tenggara dan bagaimana pencapaian pelaksanaan program CSR PT. ANTAM, Tbk Kabupaten Kolaka Sulawesi Tenggara.

Tujuan penelitian ini terdiri dari beberapa bagian yaitu untuk mengetahui tahapantahapan dalam pelaksanaan program CSR PT. ANTAM, Tbk Kabupaten Kolaka Sulawesi Tenggara dan untuk mengetahui pencapaian dari pelaksanaan program CSR PT. ANTAM, Tbk Kabupaten Kolaka Sulawesi Tenggara.

Adapun manfaat dalam penelitian ini meliputi manfaat secara teoritis yang mana penelitian ini diharapkan dapat memberikan kontribusi pemikiran pada pengembangan ilmu pengetahuan khususnya komunikasi dalam pelaksanaan corporate sosial responsibility (tanggung jawab sosial perusahaan). Kemudian manfaat secara praktis yang mana penelitian ini diharapkan dapat dimanfaatkan sebagai bahan masukan bagi pemerintah Kabupaten Kolaka dan pihak PT. ANTAM, Tbk dalam meningkatkan kesejahteraan masyarakat Kecamatan Pomalaa, dan yang terakhir manfaat secara metodologis yakni penelitian ini diharapkan dapat menjadi bahan pertimbangan bagi penulis lainnya dalam emmpelajari atau mengkaji penelitian yang sama.

Teori yang digunakan dalam penelitian ini adalah Teori Stakeholder (stakeholder theory) yang dikemukakan oleh Freeman pada tahun 1983. Teori stakeholder pada dasarnya adalah sebuah teori yang menggambarkan kepada pihak mana saja perusahaan bertanggungjawab (Freeman, 2001). Dikaitkan dengan judul penelitian ini, perusahaan yang dalam hal ini adalah PT. ANTAM, Tbk Kabupaten Kolaka Sulawesi Tenggara tentu saja bertanggung jawab terhadap masyarakat sebagai salah satu outside stakeholder yang paling terkena dampak dari aktivitas operasional perusahaan, yang dalam penelitian ini adalah masyarakat Kecamatan Pomalaa.. Hal ini berkaitan dengan pelaksanaan CSR dalam hal ini PT. ANTAM, Tbk Kabupaten Kolaka Sulawesi Tenggara yang didalamnya terimplementasi 
Jurnal Ilmu Komunikasi UHO : Jurnal Penelitian Kajian Ilmu Komunikasi dan Informasi.

Volume 6, No. 2, April 2021, hlm 179-193

Triple Bottom Line (profit, people, planet) sebagai wujud kepedulian, tangung jawab, dan komitmen moralnya kepada masyarakat agar memperoleh pengakuan dan kepercayaan yang semakin kuat dari semua stakeholder-nya, dengan demikian kehadiran perusahaan tersebut dapat diterima dalam masyarakat demi kelangsungan hidup perusahaan.

Dalam penelitian ini penulis mengambil beberapa hasil penelitian terdahulu yang mengambil objek penelitian sejenis mengenai konsep Triple Bottom Line dan Corporate Social Responsibility sebagai referensi guna memperkuat dan memperjelas tinjauan pustaka serta membandingkan penelitian-penelitian sebelumnya yang relevan dengan penelitian yang sedang dilakukan. Beberapa diantaranya adalah penelitian oleh Moh. Zulfadhli (2012) dengan judul "Pengaruh Penerapan Corporate Social Responsibility (CSR) oleh PT. RAPP Terhadap Citra Positif Perusahaan di Kalangan Masyarakat Pangkalan Kerinci Timur Kecamatan Pangkalan Kerinci, Kabupaten Pelalawan”, yang mana penelitian tersebut berfokus pada seberapa besar signifikan pengaruh penerapan CSR PT. RAP terhadap citra positif perusahaan di kalangan masyarakat, sedangkan penelitian ini fokus pada pengimplementasian konsep Triple Bottom Line pada CSR PT. ANTAM, Tbk. selain penelitian diatas, penulis juga mengambil penelitian terdahulu oleh Syaniatul Wida, (2017) dengan judul "Analisis Implementasi Corporate Social Responsibility (CSR) Terhadap Peningkatan Kesejahteraan Masyarakat Dalam Perspektif Islam (Studi Pada PT. Telkom Majapahit Bandar Lampung)", yang mana permasalahan penelitian tersebut fokus pada seberapa besar pengaruh implementasi program CSR terhadap peningkatan kesejahteraan masyarakat dalam perspektif ekonomi Islam, sedangkan penelitian ini permasalahannya fokus pada konsep triple bottom line yang digunakan sebagai dasar pelaksanaan program-program CSR PT. ANTAM, Tbk.

\section{METODE PENELITIAN}

Penelitian ini menggunakan jenis penelitian kualitatif, subjek dan informan dalam penelitian ini adalah CSR Manager PT. ANTAM, Tbk Kabupaten Kolaka Sulawesi Tenggara dan masyarakat Kecamatan Pomalaa. Informan dalam penelitian ini ditentukan dengan menggunakan Teknik Purposive, artinya informan ditentukan berdasarkan pertimbangan bahwa informan tersebut dapat memberikan informasi yang akurat serta diangap representatif dalam memperoleh data yang berkaitan dengan penelitian ini. Metode pengumpulan data yang digunakan dalam penelitian ini adalah observasi, wawancara dan studi dokumen. Data yang diperoleh dalam penelitian ini menggunakan analisis deskriptif kualitatif yakni data 
Jurnal Ilmu Komunikasi UHO : Jurnal Penelitian Kajian Ilmu Komunikasi dan Informasi.

Volume 6, No. 2, April 2021, hlm 179-193

disajikan dalam bentuk narasi kualitatif yang mencakup proses reduksi data, penyajian data, dan penarikan kesimpulan

\section{HASIL DAN PEMBAHASAN}

Penelitian ini dilakukan di Unit Bisnis Pertambangan Nikel ANTAM Sulawesi Tenggara yang terletak di Jl. Jenderal Ahmad Yani No. 5 Kecamatan Pomalaa, Kabupaten Kolaka. Berdasarkan data yang telah terkumpul dari hasil observasi, wawancara, dan dokumentasi, maka hasil pembahasan mengenai implementasi konsep Triple Bottom Line pada CSR PT. ANTAM, Tbk Sulawesi Tenggara Kab. Kolaka adalah yang diuraikan sebagai berikut.

Sesuai dengan rumusan masalah yang diangkat dalam penelitian ini, maka yang menjadi landasan teori untuk menelaah rumusan masalah diatas adalah teori stakeholder yang dikemukakan oleh Freeman (1983). Teori stakeholder pada dasarnya adalah sebuah teori yang menggambarkan kepada pihak mana saja perusahaan bertanggungjawab (Freeman, 2001). Premis dasar dari teori stakeholder adalah bahwa semakin kuat hubungan perusahaan dengan stakeholdernya, maka akan semakin baik bisnisnya, begitupun sebaliknya, semakin buruk hubungan perusahaan dengan stakeholdernya maka akan semakin sulit bisnis perusahaan. Teori stakeholder adalah sebuah konsep manajemen strategis, tujuannya adalah untuk membantu perusahaan mempererat hubungan dengan kelompok-kelompok eksternalnya.

Berkaitan dengan teori diatas, dalam penelitian ini PT. ANTAM, Tbk Sulawesi Tenggara memiliki tanggung jawab terhadap masyarakat Kecamatan Pomalaa sebagai salah satu stakeholder yang paling berpengaruh bagi perusahaan. Sebagai perusahaan tambang terbesar di Sulawesi Tenggara, aktivitas perusahaan paling berdampak pada masyarakat Kecamatan Pomalaa yang berada disekitar wilayah operasional ANTAM. Salah satu upaya ANTAM mempererat hubungan dengan masyarakat adalah dengan mengintegrasikan seluruh kebutuhan masyarakat ke dalam program CSR nya yang melibatkan masyarakat secara langsung serta transparan dalam pelaksanaannya.

Berdasarkan hasil observasi yang dilakukan oleh peneliti diketahui bahwa Mater Plan CSR UBPN ANTAM Sultra digunakan sebagai bahan acuan dan arah program jangka menengah yakni 2016-2020, sehingga terdapat kesinambungan program dari tahun ke tahun yang dapat memudahkan manajemen untuk melakukan pemantauan, evaluasi, maupun pengukuran dampak dari program yang telah dilaksanakan, serta membantu dalam mengukur 
Jurnal Ilmu Komunikasi UHO : Jurnal Penelitian Kajian Ilmu Komunikasi dan Informasi.

Volume 6, No. 2, April 2021, hlm 179-193

capaian kinerja baik itu departemen maunpun kinjera secara individual. Master Plan CSR UBPN ANTAM Sultra 2016-2020 diimplementasikan melalui Program Pengembangan Masyarakat Berkelanjutan (PPMB) melalui 3 kategori yakni Program Community Development (ComDev), Program Kemitraan dan Bina Lingkungan (PKBL) dan Kegiatan Pascatambang yang didalamnya telah terkandung unsur-unsur Triple Bottom Line.

Community Development (ComDev) merupakan program peningkatan kesejahteraan sosial ekonomi masyarakat sekaligus menjadi kategori pertama dalam melaksanakan kegiatan PPMB. Triple Bottom Line meliputi profit, people, dan planet, maka pada Program Community Development ANTAM dijabarkan menjadi 6 bidang program sesuai dengan yang telah tertuang dalam Master Plan CSR ANTAM UBPN Sultra Tahun 2016-2020, meliputi Pendidikan, Kesehatan, Ekonomi, Sosial-Budaya, Lingkungan, dan Penguatan Kapasitas Kelembagaan. Dalam pelaksanaanya ANTAM membagi lagi ComDev kedalam dua program yaitu Program Utama mencakup 6 sektor pengembangan sesuai dengan Master Plan CSR ANTAM UBPN Sultra Tahun 2016-2020, dan Program Unggulan yang hanya meliputi sektor Pendidikan, Pemberdayaan Ekonomi, dan Lingkungan karena program-programnya yang dilaksanakan secara terus-menerus dan berkelanjutan setiap tahunnya. Selain Community Development (ComDev), ANTAM juga melaksanakan Program Kemitraan dan Bina Lingkungan (PKBL) sebagai wujud pelaksanaan pronsip Good Corporate Governeance dan komitmen tanggung jawab sosial perusahaan kepada masyarakat. UBPN ANTAM Sultra mengutamakan pelaksanaan PKBL di daerah sekitar wilayah operasi Perusahaan yang terbagi menjadi dua program yakni Program Kemitraan (PK) dan Program Bina Lingkungan (BL). Program Kemitraan ditujukan khusus untuk mitra binaan ANTAM yang berfokus pada upaya pembinaan usaha mikro, kecil dan menengah (UMKM) dalam hal penyediaan modal kerja, keperluan investasi dan pembinaan usaha. Sedangkan Program Bina Lingkungan adalah program yang dilaksanakan dengan tujuan yang kurang lebih sama dengan Program Kemitraan yakni membentuk masyarakat yang sejahtera dan mandiri serta meningkatkan kapasitas perekonomian masyarakatnya yang dilakukan secara jangka panjang, namun yang membedakan adalah pada Program Bina Lingkungan sasarannya tidak terkhusus pada satu pihak melainkan untuk masyarakat luas.

\section{Tahapan-Tahapan Pelaksanaan Program CSR PT. ANTAM UBPN Sulawesi Tenggara}

Berdasarkan hasil observasi yang dilakukan, CSR UBPN ANTAM Kolaka merupakan hal yang tidak asing lagi bagi masyarakat Kabupaten Kolaka khususnya bagi masyarakat 
Jurnal Ilmu Komunikasi UHO : Jurnal Penelitian Kajian Ilmu Komunikasi dan Informasi.

Volume 6, No. 2, April 2021, hlm 179-193

Kecamatan Pomalaa seolah-olah menunjukkan bahwa ANTAM telah menjadi bagian dari masyarakat itu sendiri. UBPN ANTAM Kolaka memiliki mekanisme atau tahapan-tahapan yang selalu dipastikan dapat berjalan dengan efektif dalam pelaksanaan program CSR nya sesuai dengan tujuan yang ingin dicapai. Dari hasil observasi yang dilakukan, terdapat tiga indikator yang digunakan untuk melihat bagaimana tahapan-tahapan program CSR UBPN ANTAM Sultra dilaksanakan yakni dimulai dari tahap perencanaan strategis, kemudian tahap implementasi, hingga tahapan terkahir yaitu monitoring.

Dalam tahap perencanaan atau penyusunan program CSR UBPN ANTAM Kolaka melibatkan masyarakat dengan melakukan need assessment masyarakat atas program yang akan dilaksanakan melalui Musyawarah Rencana Pembangunan yang disebut dengan Musyawarah Rencana Pembangunan Pomalaa (MUSREMPOM) yang dihadiri oleh Lurah, Kepala Desa, dan beberapa perwakilan dari masyarakat se-Kecamatan Pomalaa yang perencanaan programnya disesuaikan dengan kebutuhan masyarakat serta rencana program pembangunan masing-masing Kelurahan/Desa. Selain MUSREMPOM, ANTAM juga sering kali melakukan musyawarah atau sosialisasi perencanaan program CSR yang khusus melibatkan masyarakat langsung. Dalam musyawarah ini, masyarakat yang berpartisipasi adalah perwakilan dari tiap-tiap Kelurahan/Desa se-Kecamatan Pomalaa. UBPN ANTAM Kolaka juga melakukan assessment secara mandiri yang dilaksanakan setiap dua tahun sekali yang disebut dengan social mapping yaitu tim dari ANTAM dalam hal ini adalah pihak ketiga melakukan survei, observasi, dan wawancara langsung ke masyarakat dengan tujuan untuk melihat potret keadaan atau masalah sosial masyarakat mulai dari pendidikan, kesehatan, tingkat kesejahteraan, sanitasi dan lain sebagainya. Social mapping inilah yang nanti akan menjadi salah satu "bahan baku" atau dasar dalam perencaan program CSR kedepannya. ANTAM juga membuka kesempatan besar bagi masyarakat, UMKM, lembaga pendidikan, lembaga kesehatan, LSM, organisasi/komunitas, dan lain sebagainya yang membutuhkan bantuan baik itu berupa dana dan/atau sarana prasarana dapat mengajukan permohonan langsung kepada UBPN ANTAM Kolaka berupa proposal yang telah diketahui dan disetujui oleh pemerintah setempat yang nantinya dari permohonan bantuan tersebut akan direalisasikan secepatnya oleh pihak ANTAM.

Dalam tahap pelaksanaan/implementasi mengacu pada SOP yang telah ditetapkan sesuai dengan kebijakan internal perusahaan. Pelaksanaan CSR ANTAM menyasar langsung pada masyarakat selaku penerima manfaat program sesuai dengan jenis program yang direalisasikan. Berdasarkan hasil observasi yang dilakukan peneliti, implementasi program 
Jurnal Ilmu Komunikasi UHO : Jurnal Penelitian Kajian Ilmu Komunikasi dan Informasi.

Volume 6, No. 2, April 2021, hlm 179-193

CSR ANTAM Kolaka yang paling terlihat adalah dibidang pendidikan, kesehatan, dan lingkungan. Pada bidang pendidikan bantuan berupa sarana prasarana sekolah, seperti bantuan pembangunan pagar sekolah, kursi dan meja belajar siswa. Sedangkan dibidang kesehatan, bantuan berupa Rumah Sakit ANTAM dan peralatan kesehatan yang diberikan kepada lembaga kesehatan yang berada di Kecamatan Pomalaa. Implementasi CSR juga sangat nampak pada lingkungan sekitar daerah operasional perusahaan yang bersih dan tertata dengan rapi.

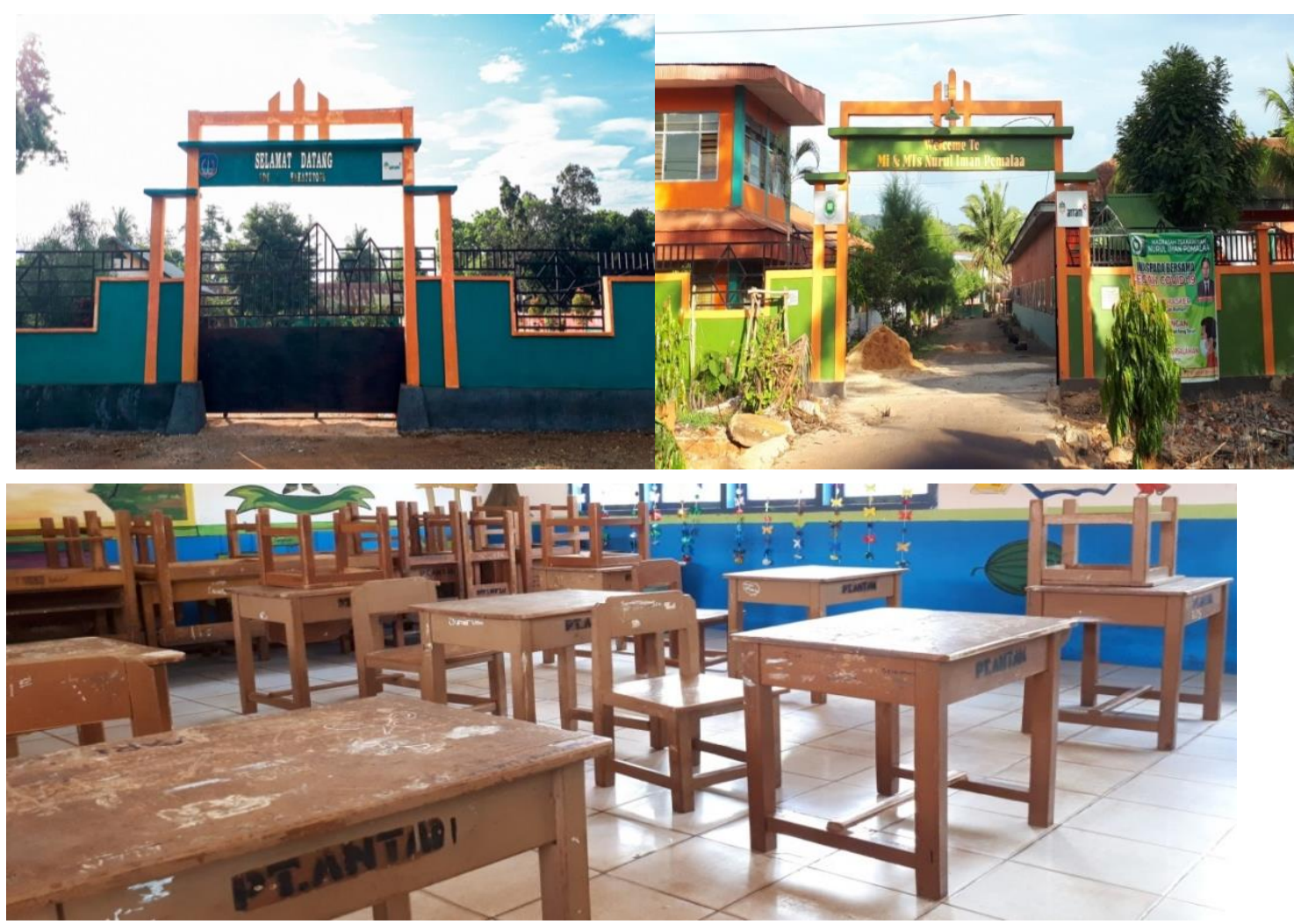

Gambar 1 Program CSR ANTAM Sektor Pendidikan Berupa Bantuan Fasilitas, Sarana, dan Prasarana

Sumber : Dokumentasi Peneliti (18 Desember 2020)

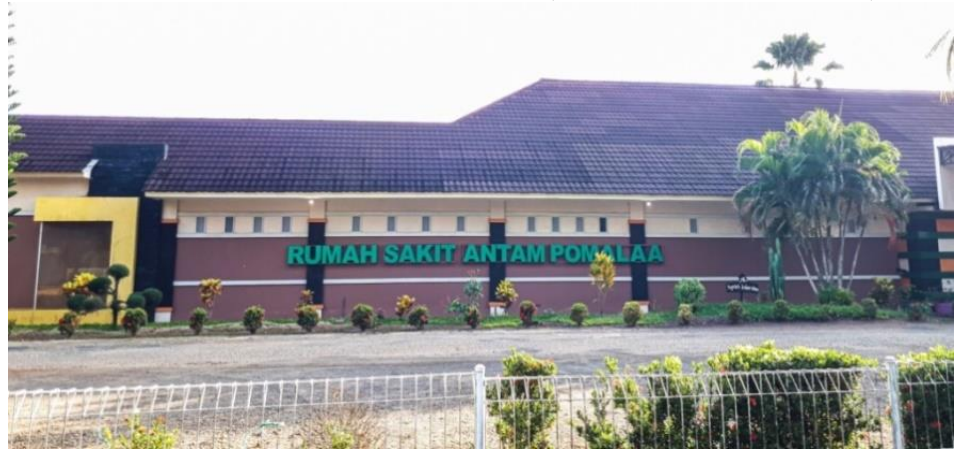

Gambar 2 Program CSR ANTAM Sektor Kesehatan

Sumber : Dokumentasi Peneliti (17 Desember 2020) 
Jurnal Ilmu Komunikasi UHO : Jurnal Penelitian Kajian Ilmu Komunikasi dan Informasi.

Volume 6, No. 2, April 2021, hlm 179-193

Tidak hanya itu, melihat kondisi saat ini dimana sedang mewabahnya Corona Virus Desease (Covid-19), melalui program CSR ANTAM memberikan bantuan berupa pembagian masker dan handsanitizer gratis, penyemprotan desinfektan dari rumah ke rumah atau di lembaga pendidikan seperti sekolah, serta watafel portable yang ditempatkan di kantor camat, kantor kelurahan/desa, puskesmas, dan pasar Dawi-Dawi.

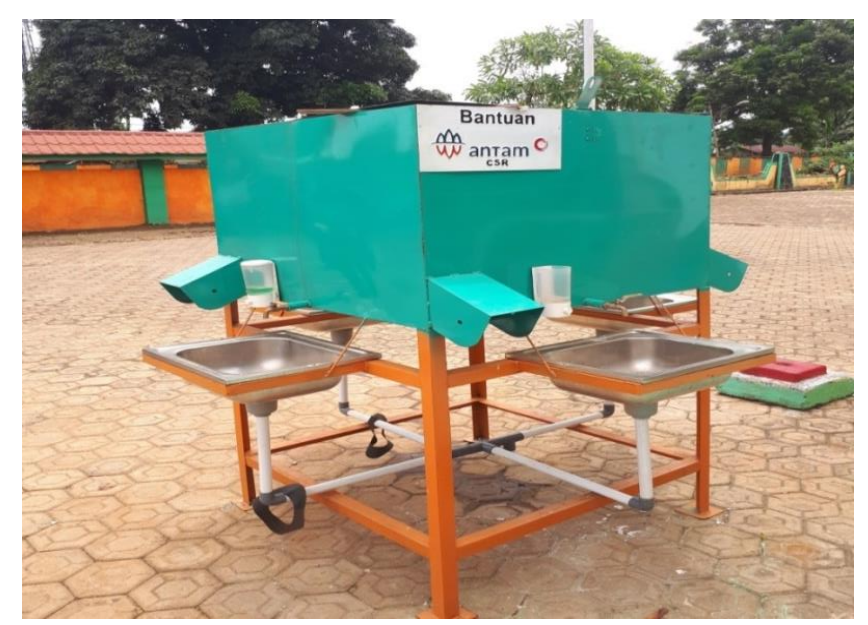

Gambar 3 Program CSR ANTAM Berupa bantuan Wastafel Portable

Sumber : Dokumentasi Peneliti (17 Desember 2020)

Selanjutnya tahapan monitoring dilaksanakan dengan melakukan survei Community Satisfaction Index (CSI) atau Indeks Kepuasan Masyarakat (IKM) untuk mengetahui jika ada kesenjangan antara perencanaan dan pencapaian program yang telah dilaksanakan. Berdasarkan hasil wawancara, dalam melaksanakan monitoring UBPN ANTAM Sultra melibatkan external relations atau pihak ketiga yang biasanya adalah mahasiswa yang di briefing terlebih dahulu sebagai pendamping pihak perusahaan dalam berinteraksi dan berkomunikasi langsung dengan masyarakat seperti membagikan kuisioner serta melakukan wawancara yang nantinya akan menjadi bahan evaluasi bagi internal perusahaan.

\section{Pencapaian Pelaksanaan Program CSR PT. ANTAM UBPN Sulawesi Tenggara}

Berdasarkan hasil observasi yang dilakukan diketahui bahwa CSR UBPN ANTAM Kolaka mengukur pencapaiannya dari seberapa besar tingkat kepuasan masyarakat terhadap program-program yang telah dilaksanakan. Tingkat kepuasan terhadap program CSR UBPN ANTAM Kolaka diukur berdasarkan Community Satissfaction Index (CSI) atau Indeks Kepuasan Masyarakat (IKM) yang dilaksanakan setiap tahun guna memastikan bahwa program-program yang telah dilaksanakan sesuai dengan kepentingan dan harapan masyarakat, terkhusus untuk melihat sejauh mana dampak program tersebut bermanfaat bagi masyarakat pengguna program. Hasil dari CSI akan menjadi gambaran kondisi masyarakat 
Jurnal Ilmu Komunikasi UHO : Jurnal Penelitian Kajian Ilmu Komunikasi dan Informasi.

Volume 6, No. 2, April 2021, hlm 179-193

penerima program serta dapat melihat wujud nyata komitmen UBPN ANTAM Kolaka dalam melaksanakan program CSR. Yang mana dalam melakukan pengukuran Indeks Kepuasan Masyarakat (IKM) ini ANTAM menggunakan metode kuantitatif (survei) yang dianalisis dengan pendekatan Customer Satisfaction Index (CSI) atau Top-Bottom Three Boxes (Skala 1 s/d 4) dan analisis kuadran untuk menentukan program-program dalam rangka meningkatkan kepuasan mitra ANTAM.

Disamping itu, peneliti menggunakan dua indikator untuk melihat sejauh mana pencapaian pelaksanaan program CSR UBPN ANTAM Sultra yaitu dilihat dari manfaat yang diberikan kepada masyarakat dan lingkungan, serta keuntungan apa saja yang didapatkan perusahaan

Berdasarkan hasil observasi yang dilakukan peneliti diketahui bahwa masyarakat Kecamatan Pomalaa banyak sekali merasakan manfaat dari pelaksanaan program CSR UBPN ANTAM Sultra. Sesuai dengan fokus ANTAM yaitu pembangunan secara berkelanjutan, program CSR pun dilaksanakan tidak hanya sekedar memberikan bantuan dana melainkan masyarakat juga diberdayakan untuk menjadi mandiri dan produktif yang pada akhirnya berdampak pada peningkatan kesejahteraan masyarakat.

Implementasi program CSR UBPN ANTAM Sultra banyak memberikan manfaat kepada masyarakat Kecamatan Pomalaa selaku masyarakat yang berada di daerah operasional perusahaan, yang secara umum adalah sebagai berikut: (1) peningkatan kualitas dan akses layanan di sektor pendidkan Kecamatan Pomalaa (melalui program pengembangan kompetensi tenaga pendidik dan kependidikan, bantuan pembangunan sarana dan prasarana serta infrastruktur sekolah, dan bantuan beasiswa bagi putra dan putri asal Kecamatan Pomalaa yang berprestasi dan bersasal dari keluarga yang tidak mampu); (2) pencegahan dan pengurangan jumlah msyarakat yang sakit melalui program optimalisasi kesehatan, pengembangan kualitas kesehatan, bantuan pembangunan dan renovasi fasilitas kesehatan masyarakat, pemberian jaminan kesehatan, penyediaan air bersih, dan bantuan lainnya; (3) peningkatan kesejahteraan masyarakat melalui program pengembangan ekonomi lokal beberapa diantaranya meliputi pengembangan UMKM, pemberdayaan nelayan pesisir, serta bantuan pengadaan sarana dan fasilitas penunjang ekonomi masyarakat; (4) mempertahankan nilai-nilai kearifan lokal serta pelestarian adat istiadat di Kecamatan Pomalaa melalui bantuan donasi, pembangunan sara/prasarana keagamaan dan olahraga, serta konribusi kegiatan sosial-budaya. (5) kelestarian lingkungan terjaga dan meminimalisir dampak negative yang 
Jurnal Ilmu Komunikasi UHO : Jurnal Penelitian Kajian Ilmu Komunikasi dan Informasi.

Volume 6, No. 2, April 2021, hlm 179-193

ditimbulkan dari aktivitas perusahaan, salah satunya melalui program perlindungan dan pelestarian keanekaragaman hayati.

Selain manfaat yang dirasakan oleh masyarakat, keuntungan terbesar yang diperoleh dari pelaksanaan CSR bagi perusaahaan itu sendiri adalah ANTAM tetap bisa beroperasi hingga saat ini karena melalui program-program CSR yang telah dilaksanakan, UBPN ANTAM Sultra dapat membangun hubungan baik dan harmonis dengan masyarakat yang berada di daerah operasional perusahaan, dalam hal ini adalah masyarakat Kecamatan Pomalaa. Dengan terjalinnya hubungan baik ini, berdampak pada eksistensi dan kredibilitas serta citra positif perusahaan dimata masyarakat. Hal ini juga berdampak pada kelanjutan hidup perusahaan yang sampai saat ini dapat bertahan salah satunya dikarenakan oleh kepercayaan dan dukungan masyarakat Kecamatan Pomalaa yang meilhat bahwa ANTAM telah sepenuhnya melaksanakan tanggung jawab sosialnya dengan mengutamakan apa yang benar-benar menjadi kebutuhan masyarakat sehingga setiap program CSR yang dilaksanakan bermanfaat dan memberikan keuntungan bagi masyarakat serta dapat meminimalisir dampak negatif yang ditimbulkan dari operasional perusahaan dan dapat memaksimalkan dampak positif bagi kelestarian lingkungan. Dari hasil penelitian yang dilakukan dapat dilihat bahwa bagi UBPN ANTAM Kolaka, CSR merupakan faktor penting yang menjadi pelengkap dalam mempertahakankan eksistensi, kredibilitas, dan citra positifnya di masyarakat.

Eksistensi, kredibilitas, dan citra positif ANTAM dimasyarakat Kecamatan Pomalaa merupakan keuntungan terbesar yang didapatkan hingga ANTAM tetap dapat beroperasi sampai saat ini. Jika ditinjau menggunakan Teori Stakeholder yang dikemukakan oleh Freeman pada tahun 1983, dianggap memiliki keterkaitan karena teori ini mengasumsikan bahwa eksistensi perusahaan memerlukan dukungan stakeholder yang dalam penelitian ini adalah masyarakat, sehingga aktivitas perusahaan juga mempertimbangkan persetujuan stakeholder. Sebagai sebuah perusahaan yang aktivitas operasionalnya berdampak pada lingkungan dan masyarakatnya, tentu saja dukungan masyarakat adalah unsur terpenting yang perlu didapatkan untuk mempertahankan kelangsungan hidup perusahaan. Untuk itu ANTAM melihat bahwa hubungan baik, kepercayaan yang kuat, dan pengakuan masyarakat Kecamatan Pomalaa yang hal ini sebagian besar didapatkan melalui implementasi programprogram CSR ANTAM yang dianggap sebagai manfaat dan sumber potensial bagi perusahaan untuk bertahan hidup, hal ini jika diibaratkan adalah sebagai sebuah simbiosis mutualisme atau hubungan yang saling memberikan manfaat, ANTAM melaksanakan tanggung jawab sosialnya dalam mengendalikan dampak yang ditimbulkan dari aktivitas 
Jurnal Ilmu Komunikasi UHO : Jurnal Penelitian Kajian Ilmu Komunikasi dan Informasi.

Volume 6, No. 2, April 2021, hlm 179-193

perusahaan dan masyarakat memberikan kepercayaannya serta mengakui dan menerima dengan positif keberadaan dari ANTAM itu sendiri.

Jika dilihat menggunakan konsep Triple Bottom Line, CSR UBPN ANTAM Kolaka telah mengimplementasikan profit, people, dan planet melalui 6 bidang program utama yakni pendidikan, kesehatan, ekonomi, sosial-budaya, lingkungan dan penguatan kapasitas kelembagaan yang tentu saja telah dipertimbangkan dengan baik agar selaras dengan norma, nilai-nilai, dan kepentingan masyarakat itu sendiri. Jika ditinjau satu-persatu, profit atau keuntungan terbesar yang diperoleh UBPN ANTAM Sultra adalah eksistensi, kredibilitas, dan citra positif yang selalu terjaga dimata masyarakat yang membuat perusahaan hingga saat ini dapat terus beroperasi tanpa adanya penolakan. Masyarakat menerima dengan keberadaan ANTAM karena dianggap sebagai perusahaan yang bertanggung jawab atas lingkungan operasionalnya serta banyak memberikan kontribusi positif. Kemudian dilihat dari sisi people sesuai dengan fokus CSR ANTAM yang mengutamakan sistem berkelanjutan dengan berusaha meningkatkan kemandirian masyarakat yang berdampak pada peningkatan ekonomi lokal dan kesejahteraan masyarakat. Tidak hanya dari segi ekonomi melainkan ANTAM juga fokus pada peningkata kualitas pendidikan, kesehatan, serta peka terhadap keadaan sosialbudaya masyarakat yang diwujudkan dalam program pengembangan masyarakat (Community Development) yang bertujuan meningkatkan kesejahteraan masyarakat, antara lain melalui pemberian beasiswa, peningkatan kualitas pendidikan, pelatihan, serta kegiatan sosial yang mengarah pada bantuan masyarakat, serta program kemitraan dan bina lingkungan yang termasuk dalam Master Plan CSR ANTAM UBPN Sultra yang mana program-program ini dilaksanakan secara terus-menerus dan merata di wilayah operasi UBPN ANTAM Sultra serta manfaatnya dapat dirasakan langsung oleh sasaran programnya.

Dilihat dari sisi planet tentu sebagai perusahaan yang bergerak dibidang pertambangan memiliki dampak terhadap kelestarian lingkungan, hal ini yang mendasari ANTAM untuk selalu fokus dan berkomitmen terhadap pelestarian lingkungan yang diwujudkan melalui berbagai program pemulihan lingkungan pasca-tambang seperti Proyek Reklamasi ANTAM sesuai dengan peraturan perundangan tentang pertambangan, khususnya Peraturan Pemerintah Nomor 78 Tahun 2010 tentang Reklamasi dan Pasca Tambang (RPT). Sejak tahun 2012 ANTAM telah melakukan beberapa reklamasi dengan luasan lahan yang bervariasi setiap tahunnya dengan menanam bibit pohon kayu jangka panjang dan jarak tanam antara 2,5 meter hingga 3,0 meter, tanaman pioneer atau cepat tumbuh yakni tumbuhan sengon buto dan sengo laut, berbagai tanaman rumput laut, tanaman kayu angin. Proyek 
Jurnal Ilmu Komunikasi UHO : Jurnal Penelitian Kajian Ilmu Komunikasi dan Informasi.

Volume 6, No. 2, April 2021, hlm 179-193

Reklamasi ini merupakan wujud kepedulian akan pengembalian fungsi hutan dan lingkungan bekas tambang di beberapa wilayah yang masuk dalam daerah operasional perusahaan.

Hal tersebut didukung dengan pelaksanaan program CSR yang perencanaannya selalu melibatkan masyarakat dan mendahulukan apa yang benar-benar dibutuhkan oleh masyarakat alih-alih hanya sekedar memberikan bantuan untuk memenuhi tanggung jawab sosialnya tanpa memikirkan dampak dan manfaat bagi masyarakat itu sendiri. Tidak hanya perencanaannya saja yang melibatkan masyarakat, melainkan tahap monitoring juga melibatkan masyarakat langsung dengan meninjau beberapa hal seperti kesesuaian antara program CSR yang dilaksanakan dengan kebutuhan masyarakat, manfaat yang dirasakan oleh masyarakat penerima program, serta berbagai hal lainnya pasca pelaksanaam program CSR.

\section{SIMPULAN}

Simpulan dari hasil penelitian ini adalah konsep Triple Bottom Line (profit, people, planet) diwujudkan dalam Master Plan CSR UBPN ANTAM Sultra melalui implementasi Program Community Development serta Program Kemitraan dan Bina lingkungan mencakup 6 bidang program yaitu pendidikan, kesehatan, ekonomi, sosial-budaya, lingkungan, dan penguatan kapasitas kelembagaan. Kemudian dalam tahapan pelaksanaan program terdapat keterlibatan masyarakat yang terlihat dari partisipasi serta antusiasme yang tinggi dalam tahap perencanaan program, pelaksanaan program dimana masyarakat sebagai penerima manfaat dan monitoring pasca pelaksanaan program, serta pencapaian pelaksanaan program terlihat dari banyaknya manfaat dari setiap program CSR UBPN ANTAM Sultra yang telah dirasakan baik itu bagi kesejahteraan masyarakat maupun bagi lingkungan yang berdampak pada eksistensi dan kredibilitas serta membentuk citra positif perusahaan di masyarakat. 
Jurnal Ilmu Komunikasi UHO : Jurnal Penelitian Kajian Ilmu Komunikasi dan Informasi.

Volume 6, No. 2, April 2021, hlm 179-193

\section{DAFTAR PUSTAKA}

Book

Effendy, Onong Uchjana. 2009. Human Relation \& Public Relation. Bandung: CV. Mandar Maju.

Ruliana, Poppy. 2014. Komunikasi Organisasi: Teori dan Studi Kasus. Jakarta: PT RajaGrafindo Persada.

\section{Jurnal Online}

Anatan, L. (2013). Corporate Social Responsibility: Tinjauan Teoritis dan Praktis di Indonesia. Jurnal Ekonomi, 1 .

Nurjannah, N., Suwatno, S., \& Damayanti, W. (2017). Komunikasi Corporate Social Responsibility Pada Official Website Perusahaan Badan Usaha Milik Negara. Jurnal ASPIKOM, 3(2), 311-325.

Rahman, A. (2004). Implementasi Corporate Social Responsibility Sebagai Keunggulan Kompetitif Perusahaan. Jurnal Fakultas Hukum UII, 6(2).

Syahriani, D., \& Siwi, M. (2018). Hubungan Komunikasi Corporate Social Responsibility dengan Reputasi Perusahaan. Jurnal KMP (Jurnal Komunikasi Pembangunan), 16(1), 54-74.

Ulum, B. (2014). Pengaruh Corporate Social Responsibility Terhadap Citra (Survei Pada Warga Sekitar PT. Sasa Inti Gending-probolinggo). Jurnal Administrasi Bisnis, 8(1).

Wida, S. (2017). ANALISIS IMPLEMENTASI CORPORATE SOCIAL RESPONSIBILITY (CSR) TERHADAP PENINGKATAN KESEJAHTERAAN MASYARAKAT DALAM PERSPEKTIF EKONOMI ISLAM (Studi Pada PT. Telkom Majapahit Bandar Lampung) (Doctoral dissertation, UIN Raden Intan Lampung).

Yanti, F., \& Rasmini, N. K. (2015). Analisis Pengungkapan Triple Bottom Line Dan Faktor Yang Mempengaruhi: Studi Di Perusahaan Indonesia Dan Singapura. E-Jurnal Akuntansi, 499-512.

Zulfadhli, M. (2012). Pengaruh Penerapan Corporate Social Responsibility (CSR) oleh PT. RAPP Terhadap Citra Positif Perusahaan di Kalangan Masyarakat Pangkalan Kerinci Timur Kecamatan Pangkalan Kerinci, Kabupaten Pelalawan (Doctoral dissertation, UNIVERSITAS ISLAM NEGERI SULTAN SYARIEF KASIM RIAU). 